\title{
Histomorphological study of mucosal changes in gall bladder in a tertiary care centre
}

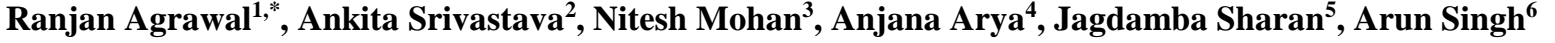 \\ ${ }_{1,3,4,6}$ Professor, ${ }^{2}$ Post Graduate Student, ${ }^{1,2,3,4}$ Dept. of Pathology, ${ }^{5}$ Dept. of Surgery, ${ }^{6}$ Dept. of Community Medicine, Rohilkhand \\ Medical College \& Hospital, Bareilly, Uttar Pradesh, India
}

*Corresponding Author:

Email: drranjan68@gmail.com

Received: $4^{\text {th }}$ March, 2018

Accepted: $20^{\text {th }}$ March, 2018

\begin{abstract}
Introduction: Gall bladder diseases are a cause of great concern. Cholelithiasis has troubled humanity since long and has been a common disease worldwide. They are among the most common gastrointestinal conditions presenting with acute pain in abdomen. Gall stone disease is usually common among middle aged females who are fertile and fatty.

Materials and Methods: The present study was conducted in in the Department of Pathology of a tertiary care teaching Institute of Western Uttar Pradesh. The study period was one year (October 2015-September 2016) with a sample size of 500 cases. Gross examination of gall bladder was done in the department and sections from representative areas were taken for microscopic examination. Special stains were used as and when required. Statistical analysis was carried out to assess the significance of various risk factors and mucosal changes in different age groups and genders.

Results: of the total 500 cases, $441(88.2 \%)$ were females and 59(11.80\%) were males. Maximum cases of gall bladder disease were in the age group of 31-40 years in both the sexes. Amongst all lesions, 394 (78.8\%) patients had gallstones and 106 (21.2\%) were acalculous. Majority of the gall stones were of mixed type in 310 (78.69\%) cases. The commonest pathological mucosal changes observed included chronic cholecystitis with cholelithiasis in 250 (62.5\%) cases. 50 cases each in the pre-malignant and malignant category were observed.

Conclusion: Gall bladder diseases are most commonly seen in females. Majority of cases were of chronic cholecystitis with cholelithiasis. Gall stones mainly injure the mucosal columnar epithelium leading to changes such as metaplasia, dysplasia or neoplasia. Knowledge of non-neoplastic as well as pre-neoplastic conditions is important especially since they cause significant morbidity or even mortality.
\end{abstract}

Keywords: Gallbladder, Cholecystectomy, Stones, Carcinoma.

\section{Introduction}

Gall bladder diseases (GBD) are more common in females than in males. ${ }^{1}$ In India, the age range of patients suffering from GBD is between 11-80 years. ${ }^{1}$ The disease is more common in the Northern and Northeastern states of Uttar Pradesh, Bihar, Orissa, West Bengal and Assam. ${ }^{2}$ The various risk factors implicated include diet, obesity and multiparity. ${ }^{3}$ Globally, cholelithiasis is more common in North America, Europe, and Australia, with a reported lower incidence in Africa, India, China, Japan and Egypt. ${ }^{4}$ In India the prevalence rate of gall stones is variable and has been reported as $2-29 \%$ with a rise in the rate in the recent years. ${ }^{2,3}$

Right upper quadrant pain followed by jaundice and presence of a palpable mass are the common clinical presentations. ${ }^{2,3}$ Ultrasonography is a rapid and accurate method to diagnose abnormalities of the gall bladder. The types of gall stones include - mixed, combined, pigment and, cholesterol types. A vast spectrum of disorders in the mucosa of gall bladder is reported. They range from inflammatory pathology to pre-malignant and extend further more to include malignant pathology as well. Malignancy especially when detected as a chance finding is important for the surgeons since it carries a significant prognostic implication. Literature search shows that gall bladder specimens in these cases that were not subjected to histopathology later presented with hepatic metastasis. ${ }^{5}$

Non-neoplastic lesions of gall bladder include acute on chronic cholecystitis, acute cholecystitis, chronic cholecystitis, hydrops, cholesterolosis (strawberry gallbladder), cholesterol polyps and porcelain gallbladder. Among the pre-malignant lesions the various entities included are polyp, adenoma, hyperplasia, metaplasia (antral or intestinal), dysplasia and xanthogranulomatous cholecystitis. ${ }^{6}$

Gallbladder cancer (GBC) is the most common malignancy of the biliary tract, accounting for $80 \%-$ $95 \%$ of biliary tract cancers. ${ }^{7-9}$ In India, cases of GBC are lesser than in the Western countries. ${ }^{10}$ Majority of the incidence of GBC in India are from the northern (Gangetic belt) and central parts of the country. $90 \%$ of GBC are adenocarcinoma type. ${ }^{11}$ The incidence rate of GBC has been reported in the age range of 29-90 years with a peak in 60 years. ${ }^{9}$

The present study was conducted with the aim of evaluating the incidence of different gall bladder disease in different categories. Also, the various mucosal changes in cholecystectomy specimens were studied. 


\section{Materials and Methods}

All the resected cholecystectomy specimens received in the Department of Pathology, Rohilkhand Medical College \& Hospital, Bareilly were included in the present study. This study was carried out for a period of one year (October 2015 - September 2016). Clearance from the Institutional Ethical Committee was obtained. Written consent was taken from all the patients at the time of admission. A total of 500 cholecystectomy specimens were included in the present study. Detailed clinical history and relevant investigations including complete blood counts and ultrasound upper abdomen were also collected.

The specimens were thoroughly grossed and sections from representative areas were processed routinely. The slides were stained with Haematoxylin \& Eosin stain (H\&E). Special stains and immunohistochemical markers were applied as and when required.

Statistical Analysis: Data so collected were analyzed using SPSS statistical software for Windows version 17, developed by IBM SPSS Software. Chi-square test was used to analyze the differences between different groups for categorical data. Student's t-Test was used to compare parametric data of different groups. Value of $p<0.05$ was considered as statistically significant.

\section{Results and Observations}

Of the 500 cases included in the study majority of patients were females (441) accounting for $88.2 \%$ whereas males were only $59(11.8 \%)$ with the $\mathrm{M} ; \mathrm{F}$ ratio of 1:7.47 as depicted in Fig. 1. Table 1 shows the age and sex wise distribution of gall bladder diseases. It was observed that among the non-neoplastic lesions maximum cases were in the age group of 31-40 years for both the sexes. In the pre-malignant category majority of the male patients were in the age range of 41-50 years, whereas female patients in the 31-40 years range were maximally affected. Amongst males, both the age group of 41-50 and 51-60 years were affected in the malignant category, but for females 41-50 years had the maximum number of cases (Fig. 2). Mixed stones were most commonly observed types in $310(78.69 \%)$ cases, followed by pigment in $34(8.63 \%)$, combined in $29(7.37 \%)$ and, pure cholesterol stones in 21(5.33\%) cases (Fig. 3).

Out of the total 400 non-neoplastic lesions included in the present study, the most common mucosal change observed was chronic cholecystitis with cholelithiasis in $250(62.5 \%)$ cases. This constituted $80 \%$ of the total non-neoplastic lesions. The second most common finding was chronic cholecystitis in $47(11.75 \%)$ cases. $23(5.75 \%)$ cases of chronic cholecystitis with cholelithiasis and cholesterolosis were observed, followed by $22(5.5 \%)$ cases of chronic cholecystitis with cholelithiasis and reactive hyperplasia of lymph node (Table 2).
A total of 50 pre-malignant lesions were included in the present study. The most common pre-malignant mucosal change observed was chronic cholecystitis with dysplasia in $15(30 \%)$ cases, followed by $13(26 \%)$ cases of chronic cholecystitis with cholelithiasis and dysplasia. $4(8 \%)$ cases each of xanthgranulomatous cholecytitis and chronic cholecystitis with cholelithiasis and intestinal metaplasia were reported (Table 3).

Of the total 50 malignant lesions observed in our study, the most common histopathological diagnosis was well-differentiated adenocarcinoma with cholelithiasis and intestinal metaplasia in 22(44\%), followed by well-differentiated adenocarcinoma with antral metaplasia in $11(22 \%)$ cases. $4(8 \%)$ cases of moderately differentiated adenocarcinoma with mild dysplasia were observed in the present study. Four cases of signet ring cell carcinoma were included. All these four cases had co-existent cholelithiasis as well (Table 4). Help of immunohistochemical markers was taken in problematic cases especially in welldifferentiated adenocarcinoma and early cases of malignancy. Association of gall stones with carcinoma was statistically significant with a $p$ value of $<0.05$.

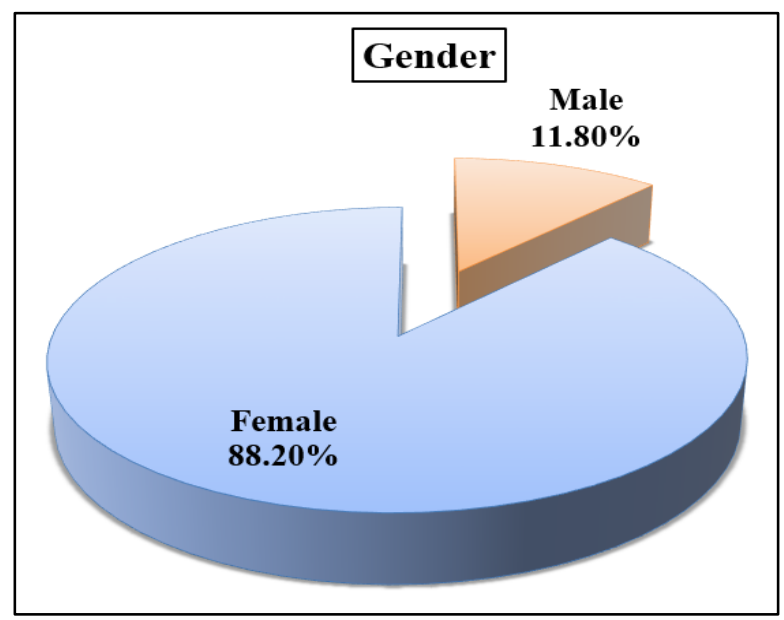

Fig. 1: Graph showing gender wise incidence of gall bladder lesion 


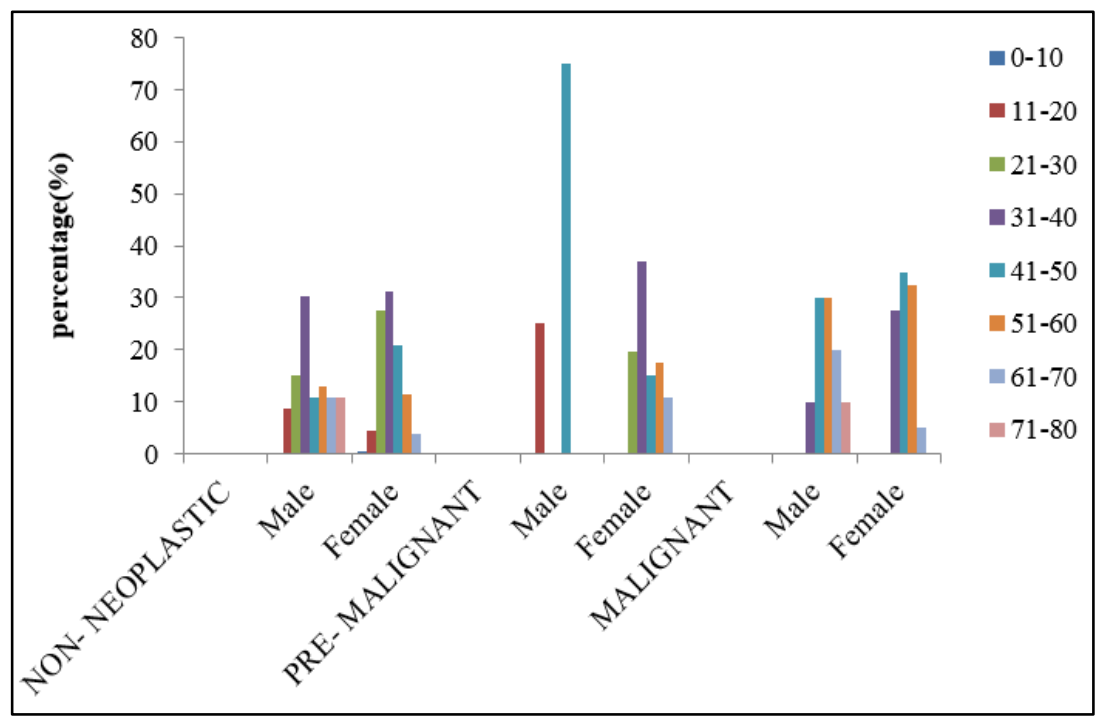

Fig. 2. Graph showing age wise distribution of gall bladder lesion in males \& females

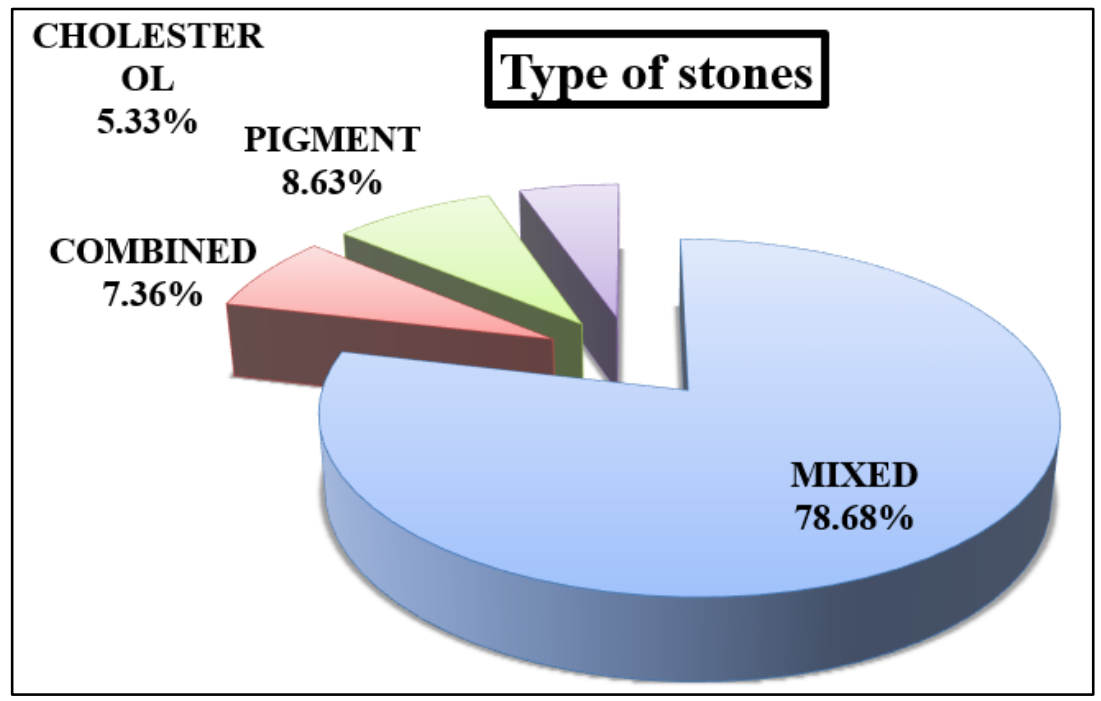

Fig 3. Distribution of cases according to the types of gall stones

Table 1: Age and sex wise distribution of gall bladder lesion

\begin{tabular}{|c|c|c|c|c|c|c|c|c|c|c|c|c|}
\hline \multirow{2}{*}{$\begin{array}{c}\text { Age } \\
\text { (In years) } \\
\end{array}$} & \multicolumn{4}{|c|}{ Non- neoplastic } & \multicolumn{4}{|c|}{ Pre-malignant } & \multicolumn{4}{|c|}{ Malignant } \\
\hline & Male & $\%$ & Females & $\%$ & Male & $\%$ & Females & $\%$ & Male & $\%$ & Females & $\%$ \\
\hline $0-10$ & - & & 2 & 0.6 & - & & - & & - & & - & \\
\hline $11-20$ & 4 & 8.7 & 16 & 4.5 & 1 & 25 & - & & - & & - & \\
\hline $21-30$ & 7 & 15.2 & 98 & 27.7 & - & & 9 & 19.6 & - & & - & \\
\hline $31-40$ & 14 & 30.4 & 110 & 31.1 & - & & 17 & 37.0 & 1 & 10 & 11 & 27.5 \\
\hline $41-50$ & 5 & 10.9 & 74 & 20.9 & 3 & 75 & 7 & 15.2 & 3 & 30 & 14 & 35 \\
\hline $51-60$ & 6 & 13.0 & 40 & 11.3 & - & & 8 & 17.4 & 3 & 30 & 13 & 32.5 \\
\hline $61-70$ & 5 & 10.9 & 14 & 4.0 & - & & 5 & 10.9 & 2 & 20 & 2 & 5.0 \\
\hline $71-80$ & 5 & 10.9 & - & & - & & - & & 1 & 10 & - & \\
\hline \multirow[t]{2}{*}{ Total } & 46 & & 354 & & 4 & & 46 & & 10 & & 40 & \\
\hline & \multicolumn{4}{|c|}{$\begin{array}{c}* \mathrm{X}^{2}-38.17, \mathrm{p}=0.000(\text { Highly } \\
\text { Significant }) .\end{array}$} & \multicolumn{4}{|c|}{$\begin{array}{c}* \mathrm{X}^{2}-20.9, \mathrm{p}=0.000(\text { Highly } \\
\text { Significant }) .\end{array}$} & \multicolumn{4}{|c|}{$\begin{array}{c}* \mathrm{X}^{2}-1.14, \mathrm{p}=0.887(\mathrm{Not} \\
\text { Significant). }\end{array}$} \\
\hline
\end{tabular}


Table 2: Histopathological distribution of non-neoplastic lesions of gall bladder

\begin{tabular}{|c|c|c|c|c|}
\hline \multirow[t]{2}{*}{ Diagnosis } & \multicolumn{2}{|c|}{ No. of Cases } & \multirow[t]{2}{*}{ Total } & \multirow[t]{2}{*}{$\%$} \\
\hline & Males & Females & & \\
\hline Acute cholecystitis & - & 1 & 1 & 0.25 \\
\hline Acute on chronic cholecystitis & - & 4 & 4 & 1 \\
\hline Acute on chronic cholecystitis with cholelithiasis & - & 8 & 8 & 2 \\
\hline Chronic cholecystitis & 7 & 40 & 47 & 11.75 \\
\hline Follicular cholecystitis & - & 1 & 1 & 0.25 \\
\hline Chronic follicular cholecystitis with cholelithiasis & 2 & 4 & 6 & 1.5 \\
\hline Chronic cholecystitis with cholelithiasis & 30 & 220 & 250 & 62.5 \\
\hline Chronic cholecystitis with cholesterosis & 2 & 7 & 9 & 2.25 \\
\hline Chronic cholecystitis with cholelithiasis \& cholesterosis & 2 & 21 & 23 & 5.75 \\
\hline $\begin{array}{l}\text { Chronic cholecystitis with cholelithiasis \& dystrophic } \\
\text { calcification }\end{array}$ & - & 8 & 8 & 2 \\
\hline $\begin{array}{l}\text { Chronic cholecystitis with cholelithiasis \& cholesterosis \& } \\
\text { dystrophic calcification }\end{array}$ & - & 1 & 1 & 0.25 \\
\hline Chronic cholecystitis with adenomyomatosis & - & 1 & 1 & 0.25 \\
\hline $\begin{array}{l}\text { Chronic cholecystitis with cholelithiasis \& cholesterosis \& } \\
\text { adenomyomatosis }\end{array}$ & - & 1 & 1 & 0.25 \\
\hline Chronic cholecystitis with cholesterol polyp & 1 & & 1 & 0.25 \\
\hline $\begin{array}{l}\text { Chronic cholecystitis with cholelithiasis \& hyperplasia of } \\
\text { lymph node }\end{array}$ & 4 & 18 & 22 & 5.5 \\
\hline $\begin{array}{l}\text { Chronic cholecystitis with cholelithiasis \& hyperplasia of } \\
\text { lymph node \& dystrophic calcification }\end{array}$ & - & 1 & 1 & 0.25 \\
\hline $\begin{array}{l}\text { Chronic cholecystitis with cholelithiasis \& tubercular } \\
\text { lymphadenitis }\end{array}$ & - & 1 & 1 & 0.25 \\
\hline Eosinophilic cholecystitis with cholelithiasis & 3 & 12 & 15 & 3.75 \\
\hline Total & 51 & 349 & 400 & \\
\hline
\end{tabular}

Table 3. Histopathological distribution of pre-malignant lesions of gall bladder

\begin{tabular}{|l|c|c|c|c|}
\hline Diagnosis & \multicolumn{2}{|c|}{ No. of cases } & Total & \% \\
\hline Chronic cholecystitis with intestinal metaplasia & - & 3 & 3 & 6 \\
\hline $\begin{array}{l}\text { Chronic cholecystitis with cholelithiasis \& intestinal } \\
\text { metaplasia }\end{array}$ & 1 & 3 & 4 & 8 \\
\hline $\begin{array}{l}\text { Chronic cholecystitis with cholesterosis \& intestinal } \\
\text { metaplasia }\end{array}$ & 1 & - & 1 & 2 \\
\hline $\begin{array}{l}\text { Chronic cholecystitis with cholelithiasis \& } \\
\text { cholesterosis \& intestinal metaplasia }\end{array}$ & - & 3 & 3 & 6 \\
\hline $\begin{array}{l}\text { Chronic cholecystitis with cholelithiasis \& antral } \\
\text { metaplasia }\end{array}$ & - & 3 & 3 & 6 \\
\hline $\begin{array}{l}\text { Chronic cholecystitis with cholesterosis \& antral } \\
\text { metaplasia }\end{array}$ & - & 1 & 1 & 2 \\
\hline $\begin{array}{l}\text { Chronic cholecystitis with cholelithiasis \& } \\
\text { cholesterosis \& antral metaplasia \& lymph node } \\
\text { hyperplasia }\end{array}$ & 1 & - & 1 & 2 \\
\hline $\begin{array}{l}\text { Eosinophilic cholecystitis with cholelithiasis \& } \\
\text { squamous metaplasia }\end{array}$ & - & 1 & 1 & 2 \\
\hline Chronic cholecystitis with dysplasia & 2 & 13 & 15 & 30 \\
\hline Chronic cholecystitis with cholelithiasis \& dysplasia & 2 & 11 & 13 & 26 \\
\hline Xanthogranulomatous cholecystitis & - & 4 & 4 & 8 \\
\hline Xanthogranulomatous cholecystitis with cholelithiasis & - & 1 & 1 & 2 \\
\hline Total & 7 & 43 & 50 & \\
\hline
\end{tabular}


Table 4: Histopathological distribution of malignant lesions of gall bladder

\begin{tabular}{|l|c|c|c|c|}
\hline Diagnosis & \multicolumn{2}{|c|}{ No. of cases } & Total & \% \\
\hline $\begin{array}{l}\text { Well differentiated adenocarcinoma with cholelithiasis \& } \\
\text { intestinal metaplasia }\end{array}$ & 3 & 19 & 22 & 44 \\
\hline Well differentiated adenocarcinoma with antral metaplasia & 4 & 7 & 11 & 22 \\
\hline $\begin{array}{l}\text { Well differentiated adenocarcinoma with metastatic } \\
\text { deposits in lymph nodes }\end{array}$ & 1 & 1 & 2 & 4 \\
\hline $\begin{array}{l}\text { Well differentiated adenocarcinoma with cholelithiasis \& } \\
\text { metastatic deposits in lymph nodes }\end{array}$ & - & 1 & 1 & 2 \\
\hline $\begin{array}{l}\text { Moderately differentiated adenocarcinoma } \\
\text { With mild dysplasia }\end{array}$ & 1 & 3 & 4 & 8 \\
\hline $\begin{array}{l}\text { Moderately differentiated adenocarcinoma with } \\
\text { cholelithiasis }\end{array}$ & - & 1 & 1 & 2 \\
\hline $\begin{array}{l}\text { Moderately differentiated adenocarcinoma with metastasis } \\
\text { in lymph node }\end{array}$ & - & 1 & 1 & 2 \\
\hline $\begin{array}{l}\text { Moderately differentiated adenocarcinoma with } \\
\text { cholelithiasis \& metastasis in lymph nodes with moderate } \\
\text { dysplasia }\end{array}$ & 1 & 1 & 2 & 4 \\
\hline Poorly differentiated adenocarcinoma with cholelithiasis & - & 1 & 1 & 2 \\
\hline Adenosquamous carcinoma with cholelithiasis & - & 2 & 2 & 4 \\
\hline $\begin{array}{l}\text { Papillary adenocarcinoma with cholelithiasis } \\
\text { Severe dysplasia }\end{array}$ & - & 1 & 1 & 2 \\
\hline Signet ring cell adenocarcinoma & - & 2 & 2 & 4 \\
\hline Total & 10 & 40 & 50 & \\
\hline
\end{tabular}

\section{Discussion}

Gall stones are one of the major causes of morbidity and mortality all over the world affecting $10 \%$ of all adult population. ${ }^{12}$ Various epithelial pathological changes in the gall bladder mucosa can be ruled out with the help of clinico-radiological examination and extensive histological evaluation to prevent cancer related morbidity and mortality.

GBD is most commonly observed in females. In the present study, females were most commonly affected by gall bladder diseases than males with a M:F ratio of 1:7.47. This observation is consistent with the findings of Shah T et al, Mehariya et al and, Mohan et al. ${ }^{12-14}$ Amongst males, both the age group of 41-50 and 51-60 years were affected in the malignant category, but for females 41-50 years had the maximum number of cases. This was in sharp contrast to the observations of previous authors. ${ }^{15-16}$

Mixed stones were the commonest type of gallstones, (62\%) as observed in the present study. This was consistent with the findings of Mazlum $\mathrm{M}$ et al $(67.50 \%),{ }^{17}$ Mathur SK et al $(59 \%)^{18}$ in contrast to the observations of Goyal S et $a l^{19}$ and, Vahini G et al ${ }^{20}$ who reported maximum cases of mixed gall stones (44 cases).

In the present study, of the total 400 non-neoplastic lesions, the most common non-neoplastic histopathological diagnosis established was chronic cholecystitis with cholelithiasis in $250(62.5 \%)$ forming $80 \%$ of total non-neoplastic lesions. This was consistent with the findings of Damor NT et al. ${ }^{21}$ Observations by
Siddiqui FG et al and, Soomro AG et al found that maximum cases were of chronic cholecystitis. ${ }^{15,22}$ Mehariya MK et al and Sharma I et al reported chronic calculus cholecystitis as the most common lesion which was similar to the findings of our study. ${ }^{13,23}$ Cholesterosis is an important stromal change in gall bladders. Majority of these cases are associated with cholesterol type gall stones. ${ }^{5,23}$

In the present study, of the total 50 pre-malignant cases of gall bladder, maximum 15 (30\%) cases are of chronic cholecystitis with dysplasia followed by 13 (26\%) cases of chronic cholecystitis with cholelithiasis and dysplasia and 4(8\%) cases each of chronic cholecystitis with cholelithiasis \& intestinal metaplasia and xanthogranulomatous cholecystitis. Baidya $\mathrm{R}$ et al in their study on 60 cholecystectomy specimens found 2 cases of metaplasia and, 8 cases of dysplasia. ${ }^{24}$ Sharma I et al in their study on 348 gall bladder specimens found $2(0.62 \%)$ cases of chronic cholecystitis with evidence of intestinal metaplasia, $4(1.3 \%)$ cases of xanthogranulomatous cholecystitis, $4(1.3 \%)$ cases of chronic cholecystitis with dysplastic changes which was similar to our study. ${ }^{23}$

Incidence of Metaplasia reported in our study was $3.2 \%$ this is in contrast to $25.9 \%$ metaplasia reported by Agrawal et al. ${ }^{5}$ Intestinal metaplasia is more common than antral metaplasia as on contrast to that of. Agrawal et al, who observed antral metaplasia to be more common. ${ }^{5}$ Xanthogranulomatous cholecystitis is an important of morphological change. Increased incidence of carcinoma is associated with 
xanthogranulomatous pathology as reported earlier also $^{5,14}$ dysplasia is mostly associated with gall stones and that too mixed type. The observations are similar to these of the previous studies. ${ }^{16}$

GBC which is the third most common cancer of gastrointestinal tract. ${ }^{14}$ Gall bladder cancer is most common in the Northern and Northeastern States of India. ${ }^{15}$ In present study, out of 50 cases of malignant lesions of gall bladder, 22 (44\%) cases are of well differentiated adenocarcinoma with cholelithiasis and intestinal metaplasia. Similar findings were reported by Mathur SK et al who studied gall bladder lesions and found $8(2 \%)$ cases of carcinoma out of 330 cases, in which, 7 of them adenocarcinomas. ${ }^{18}$ Observation made by Hamdani $\mathrm{NH}$ et al and Rosai pointed out that adenocarcinoma $(87.7 \%)$ was the commonest histological type which was consistent with the findings of the present study. ${ }^{25,}{ }^{26}$ Risk of developing GBC is much higher in patients that have symptomatic gallstones as compared to the ones having silent stones. Considering this fact it has been recommended by various authors in their studies that prophylactic cholecystectomy should be done in young women especially in Northern India who present with symptoms of gall stone disease. ${ }^{11}$ However, few other authors deny this contention.

Early cases of gall bladder malignancy may show desmoplastic reaction resulting in thickening of walls, thus closely mimicking cases of chronic cholecystitis. This further signifies the role of histopathology in all the cases. ${ }^{27}$

\section{Conclusion}

Cholelithiasis and cholecystitis result in a series of pathological mucosal changes which represent the precursor lesions of carcinoma. Antral metaplasia and intestinal metaplasia are precursors of dysplasia in gall bladder. Screening of pre-malignant lesions is necessary to reduce mortality and morbidity among high-risk patients. An appropriate early measure is important for curative treatment and long-term survival of patients. Histopathological examination is thus important in every case of cholecystectomy for identifying metaplasia, dysplasia or carcinoma.

\section{References}

1. Sood S, Kumar R, Varshney A, Sharma VK, Mohan A, Wadhwa B et al. A histopathological study of nonneoplastic gall bladder diseases with special reference to mucin histochemistry. Annals of Applied Bio-Sciences. 2016;3(2):189-195.

2. Unisa S, Jagannath P, Dhir V, Khandelwal C, Sarangi L, Roy TK. Population-based study to estimate prevalence and determine risk factors of gallbladder diseases in the rural Gangetic basin of North India. $H P B$, 2011;13(2):117-25.

3. Randi G, Franceschi S, La Vecchia C. Gallbladder cancer worldwide: geographical distribution and risk factors. Intl J Cancer. 2006;118(7):1591-602.
4. Prakash AC, Toppo S, Pratap V. Prevalence and Management of Cholelithiasis in East India. IOSR-JDMS. 2016;15(12):34-7.

5. Agarwal S, Pandey P, Ralli M, Agarwal R, Saxena P. Morphological characterisation of 1693 cholecystectomy specimens - A study from tertiary care center in Northern India. JCDR, 2018; 12(1): 5 - 9 .

6. Sandberg AA. Diagnosis and management of gallbladder cancer. N Am J Med Sci. 2012;4(7):293-9.

7. Hundal R, Shaffer EA. Gallbladder cancer: epidemiology and outcome. Clin Epidemiol. 2014; 6:99-109.

8. Everhart JE, Khare M, Hill M, Maurer KR. Prevalence and ethnic differences in gallbladder disease in the United States. Gastroenterology. 1999; 117(3):632-9.

9. Ghosh Y, Thakurdas B. Carcinoma Gall Bladder: Past, Present, and Future. Int J BioMed. 2014;4(4):198-203.

10. Das A. Epidemiology of Gallbladder cancer among North-Eastern States of India: A Review. Int. Res. J. Medical Sci. 2016;4(6):11-5.

11. Raza MA, Mukherjee S, Prashad T, Agrawal R. Spectrum of clinic - pathological presentations of gallstone diseases in a tertiary care institute in Rohilkhand regon. $J$ Evol Med Dent Sei. 2015;4(81):14190-200.

12. Shah T, Shah P, Parmar H, Vaidya Y, Jadeja J, Patel D. Prospective single centre study of 100 patients undergoing laproscopic cholecystectomy - changing trends. NHL Journal of medical sciences. 2013;2(1):61-4.

13. Mehariya MK, Patel MB, Dhotre SV. Histopathological Study of gall Bladder. Int J Res Med. 2014;3(4):96-9.

14. Mohan H, Punia RPS, Dhawan SB, Ahal S, Sekhon S. Morphological spectrum of gall stone disease in 1100 cholecystectomees in North India. Indian J Surg 2006;67:140-42.

15. Siddiqui FG, Memon AA, Abro AH, Sasoli NA, Ahmad L. Routine histopathology of gallbladder after elective cholecystectomy for gallstones: waste of resources or a justified act. BMC Surg. 2013;13(1):1-5.

16. Gupta SC, Misra V, Singh PA, Roy A, Misra SP, Gupta $\mathrm{AK}$, Gall stones and carcinoma gall bladder. Indian $J$ Pathol Microbiol 2000;43:147-54.

17. Mazlum M, Dilek FH, Yener AN, Tokyol C, Aktepe F, Dilek ON. Profile of Gallbladder Diseases Diagnosed at Afyon Kocatepe University: A Retrospective Study. Türk Patoloji Derg. 2011;27(1):23-30.

18. Mathur SK, Duhan A, Singh S, Aggarwal M, Aggarwal $\mathrm{G}$, Sen R. Correlation of gallstone characteristics with mucosal changes in gall bladder. Trop Gastroenterol. 2012;33(1):39-44

19. Goyal S, Singla S, Duhan A. Correlation between gallstones characteristics and gallbladder mucosal changes: A retrospective study of 313 patients. Clin Cancer Investig J 2014;3(2):157-61.

20. Vahini G, Premalatha P, Mathi A, Krishna R, Renuka IV. A clinicopathological study of gallbladder lesions. IOSRJDMS. 2015;14(2):15-20.

21. Damor NT, Chauhan HK, Jadav HR. Histological study of human gallbladder. Int J Biomed Adv Res. 2013;4(9):597-601.

22. Soomro AG, Jarwar M, Ali SA, Nizamani NB, Memon AS. Frequency of Carcinoma in Gall Bladder Specimens sent for Histopathology in a University Hospital. $J$ Liaquat Uni Med Health Sci. 2013;12(1):55-9.

23. Sharma I, Choudhury D. Histopathological patterns of gall bladder diseases with special reference to incidental cases: a hospital based study. Int J Res Med Sci. 2017;3(12):3553-7. 
24. Baidya R, Sigdel B, Baidya NL. Histopathological changes in gallbladder mucosa associated with cholelithiasis. J Pathol Nepal. 2012;2(3):224-5.

25. Hamdani NH, Qadri SK, Aggarwalla R, Bhartia VK, Chaudhuri S, Debakshi S et al Clinicopathological study of gall bladder carcinoma with special reference to gallstones: our 8-year experience from eastern India. Asian Pac J Cancer Prev. 2012;13(11):5613-7.

26. Rosai J. Gall bladder and extrahepatic bile ducts. Rosai and Ackerman's Surgical Pathology. 10th Ed. Elsevier, New York 2012;981-1004.
27. Shukla HS, Sirohi B, Behari A, Sharma A, Majumdar J, Ganguly M. Indian Council of Medical Research consensus document for the management of gall bladder cancer. Ind J Med Paediatr Oncol. 2015;36(2):79-84.

How to cite this article: Agrawal R, Srivastava A, Mohan N, Arya A, Sharan J, Singh A. Histomorphological study of mucosal changes in gall bladder a tertiary care centre. Ind $\mathbf{J}$ Pathol Oncol, 2018;5(3):398-404. 